\title{
ANTIMONY FIXATION IN SOLID PHASES AT THE HYDROTHERMAL FIELD OF KOLUMBO SUBMARINE ARC-VOLCANO (SANTORINI): DEPOSITION MODEL AND ENVIRONMENTAL IMPLICATIONS
}

\section{Kilias S.P. ${ }^{1}$, Gousgouni M. ${ }^{1}$, Godelitsas A. ${ }^{1}$, Gamaletsos P. ${ }^{2}$, Mertzimekis T.J. ${ }^{3}$, Nomikou P. ${ }^{1}$, Argyraki A. ${ }^{1}$, Goettlicher J. ${ }^{4}$, Steininger R. ${ }^{4}$ and Papanikolaou D. ${ }^{1}$}

${ }^{1}$ National and Kapodistrian University of Athens(NKUA), Department of Geology and Geoenvironment,15785, Athens, Greece,mgousgouni@gmail.com, kilias@geol.uoa.gr, agodel@geol.uoa.gr,evinom@geol.uoa.gr,argyraki@geol.uoa.gr,dpapan@geol.uoa.gr

${ }^{2}$ National Technical University of Athens (NTUA), Athens, Greece, platongamaletsos@metal.ntua.gr

${ }^{3}$ National and Kapodistrian University of Athens, Department of Physics, 15785, Athens, Greece tmertzi@phys.uoa.gr

${ }^{4}$ Karlsruhe Institute of Technology, ANKA Synchrotron Facility, Hermann-von-Helmholtz-Platz 1, 76344 Eggenstein, Germany,joerg.goettlicher@kit.edu, ralph.steininger@kit.edu

\begin{abstract}
Antimony, an emergent global contaminant, that is hydrothermally discharged along with other epithermal metals(-loids) ( $\mathrm{Au}, \mathrm{As}, \mathrm{Hg}, \mathrm{Ag}, \mathrm{Tl}, \mathrm{Ag}$ ) onto Kolumbo volcano's shallow (<500 $\mathrm{m}$ water depth) crater seabed, is fixed either in pyrite, orpiment-like As-sulfides, and ferrihydrite-like Fe-oxy(hydro)oxides, or forms independent $\mathrm{Pb}(\mathrm{Zn})$ $\mathrm{Sb}$ sulfosalts, of layered Sb-rich (up to $2.2 \mathrm{wt} \%$ ) chimneys. High concentrations of Sb $(\leq 27.2 \mathrm{wt} \%)$ are found in early colloform chemically-zoned hydrothermal pyrite, and later orpiment $\left(A s_{2} S_{3}\right)$-type As-sulfide phases ( $\left.\leq 16.09 w t \%\right)$, along individual micronscale growth zones. Antimony in pyrite may occur in the relatively more toxic trivalent (or lower valence) $\left(\mathrm{Sb}^{3+}\right)$ rather than pentavalent $\left(\mathrm{Sb}^{5+}\right)$ forms. Lead $(\mathrm{Pb})$ always occurs with $\mathrm{Sb}$ in growth zones where the abundances of $\mathrm{Sb}$ and $\mathrm{Pb}$ vary inversely with $\mathrm{Fe}$ and $\mathrm{S}$, suggesting that $\mathrm{Sb}$ and $\mathrm{Pb}$ occur either as homogeneously distributed sulfosalt nanoparticles of $\mathrm{S} b$ and $\mathrm{Pb}$ and/or lattice bound trace elements. These findings indicate the solid phases that fix Sb on the seafloor are crucial for high-grade concentration during shallow-water hydrothermal polymetallic mineralization, and reducing the high hydrothermal flux of this notorious environmental toxin to seawater, near the fishing area of Santorini that is also one of the most popular tourist places in the world.
\end{abstract}

Keywords: contaminant, epithermal, Aegean.

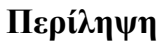

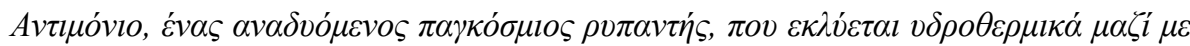

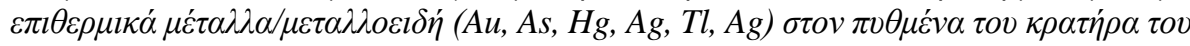

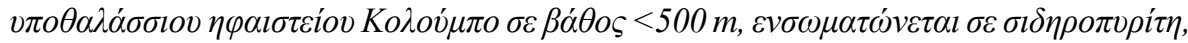

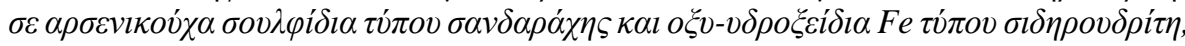




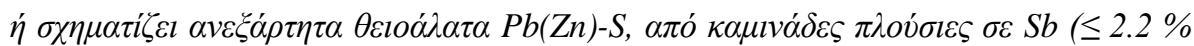

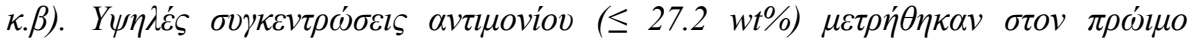

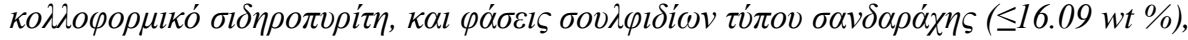

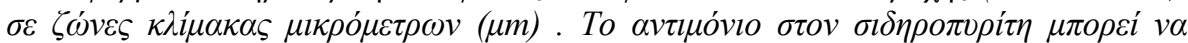

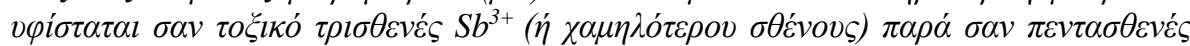

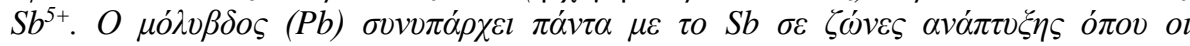

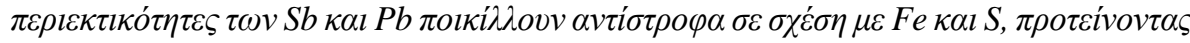

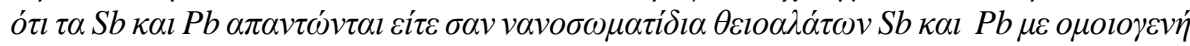

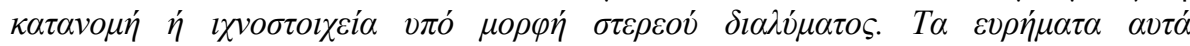

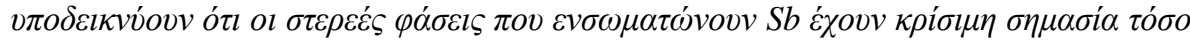

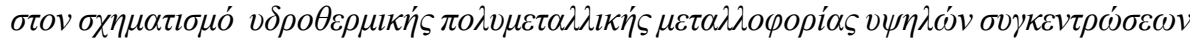

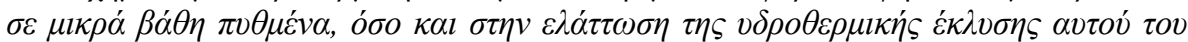

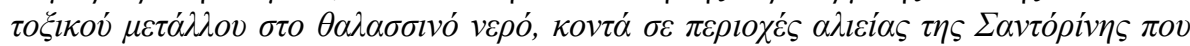

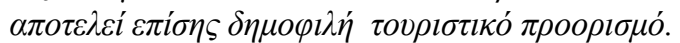

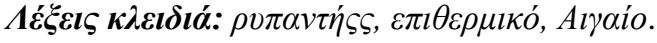

\section{Introduction}

Antimony ( $\mathrm{Sb}$ ) bears economic and environmental importance: it belongs to the critical raw materials that are crucial to Europe's economy; then again $\mathrm{Sb}$ is an emerging toxic pollutant of priority interest (e.g. EU Commission, 2014; Filella et al., 2009; Amarasiriwardena and Wu, 2011).

High amounts of $\mathrm{Sb}$ can be discharged into the oceans by continental riverine runoff affected by mining or industrial effluents (Filella et al., 2002a, b) and seafloor hydrothermal fluids which may discharge $\mathrm{Sb}$ at concentrations up to several hundred times those of seawater (e.g. Fouquet et al., 2010). The toxicity, the solubility, and adsorption properties of $\mathrm{Sb}$ to natural minerals depend on the oxidation state $\left(\mathrm{Sb}^{3+}\right.$ and $\left.\mathrm{Sb}^{5+}\right)$ (Filella et al., 2002a), however, key aspects of the environmental chemistry and the mechanisms of concentration of Sb in natural systems, and its global biogeochemical cycle, remain poorly understood. More specifically, despite its importance for understanding the genesis and metal enrichment of currently explored ancient VMS deposits (e.g. Au, which is often associated with As and $\mathrm{Sb}$ ), understanding the distribution of $\mathrm{Sb}$ and related trace metals during the formation and transformation of massive sulfides on the modern seafloor, and especially shallow submarine hydrothermal systems, remains tentative (Filella et al., 2002a; Filella et al., 2009; Majzlan and Fillela, 2012; Meleketseva et al., 2014; Wohlgemuth-Ueberwasser et al., 2015; Keith et al., 2016).

A recent study by Kilias et al. (2013) has highlighted the active Kolumbo Hydrothermal Field (KHF) of the Kolumbo shallow-submarine $(<600 \mathrm{~m})$ arc-volcano, Santorini, as an $\mathrm{Sb}( \pm \mathrm{Tl}, \mathrm{Hg})$ geochemical and potential economic anomaly compared to the rest of the Hellenic Volcanic arc (HVA), and the importance of seafloor hydrothermal activity as a source of potentially toxic trace metals in areas exploited by fishing in the Aegean Sea. The 5 Ma-to-present HVA is unique in as much that arc-volcanism and seafloor hydrothermal activity occur in thinned continental crust (Kilias et al., 2013a, and references therein).

The Kolumbo active shallow-submarine arc-volcano, Santorini (Cantner et al., 2014; Hubscher et al., 2015) belongs to an active volcano-tectonic field that runs sub-parallel to the NE-SW Christianna-Santorini-Kolumbo tectonic zone in the central HVA (Nomikou et al., 2013). The KHF $(600 \mathrm{X} 1200 \mathrm{~m})$ was discovered (Sigurdsson et al., 2006) at 492-504 m depth on the $\mathrm{N}$ floor of the density-stratified acidic ( $\mathrm{pH} \sim 5$ ) Kolumbo crater (Carey et al., 2013), and consists of Fe (oxy)hydroxide rich sediments $\left(\mathrm{T}<70{ }^{\circ} \mathrm{C}\right)$, and polymetallic diffuser chimneys and mounds, some with active bubble streaming $\left(99 \% \mathrm{CO}_{2}\right)$ and aqueous fluid shimmering at $\mathrm{T}_{\max } 220^{\circ} \mathrm{C}$. The chimneys are uniquely enriched in $\mathrm{Sb}+\mathrm{Tl}+\mathrm{Hg}$ [Sb, avg.: 8,330 ppm; max: $2.2 \mathrm{wt} \%$; Tl, avg.:510 ppm; max: 1,000 ppm; Hg, avg.: 397 ppm; max:1,070)](Kilias et al., 2013a), and comprise epithermal geochemical association ( $\mathrm{Au}, \mathrm{As}, \mathrm{Sb}, \mathrm{Hg}, \mathrm{Ag}, \mathrm{Tl}, \mathrm{Ag}$ ) and a new active analogue style of hybrid epithermal-VMS mineralization (Kilias et al., 2013a). Hydrothermal chimneys are typically layered 
comprising: (a) a thick "inner sulfide-sulfate core" (ISSC), (b) a thin outer As-sulfide dominated layer (OAsL), and, (c) an Fe oxyhydroxide-dominated microbial $\mathrm{Fe}$ crust (SFeC); interior hydrothermal conduit networks are lined by unidentified Sb-Zn-S phases (IPCN). ISSC sulfides comprise, according to powder-XRD (PXRD) and SEM-EDS, crystalline pyrite, sphalerite and galena, and a PXRD-amorphous (hereafter amorphous) $\mathrm{Pb}$-Sb sulphosalts, in a barite matrix. The OAsL consists of amorphous orpiment $\left(\mathrm{As}_{2} \mathrm{~S}_{3}\right)$-type phases within a barite and gypsum matrix, whereas amorphous ferrihydrite-type phases dominate the SFeC; the interior IPCN are lined by barite and gypsum overgrown by metallic aggregates of amorphous $\mathrm{Sb}-\mathrm{Zn}-\mathrm{S}$ phases which are overgrown by amorphous K-Mg-Al-silicate, and/or Al-K-Fe-sulphate phases (Kilias et al., 2013a).

This paper will focus on the concentration and modification of $\mathrm{Sb}$ in hydrothermal mineral phases of the KHF, and the genetic and environmental significance.

\section{Materials and Methods}

\subsection{Sampling}

The studied samples were recovered in September 2011 during the NA014 ("Hellenic Volcanic Arc and Cretan Basin") oceanographic expedition of the "New Frontiers in Ocean Exploration 2011" project (Principal Investigator Robert Ballard, Ocean Exploration Trust (OET), University of Rhode Island URI, USA). Chief scientists for NA014 were Katherine Croff Bell (Ocean Exploration Trust, University of Rhode Island (URI) USA, and Paraskevi Nomikou (NKUA, Dept. of Geology and Geoenvironment, Greece). The expedition used Exploration Vessel (E/V) Nautilus and was sponsored by: (1) Institute for Exploration (IFE), a division of Mystic Aquarium and Institute for Exploration (MAIFE); (2) National Geographic Society; (3) NOAA Office of Ocean Exploration and Research; (3) Ocean Exploration Trust (OET); (4) Office of Naval Research (ONR). The E/V Nautilus is owned and operated by the Ocean Exploration Trust and University of Rhode Island (URI)-Center for Ocean Exploration and is equipped with the remotely operated vehicles (ROVs) Hercules and Argus. Sampling campaign and methods are detailed in Ocean Exploration Trust and URI Center for Ocean Exploration-State File No. F2011-049 (2012) and Kilias et al. (2013a).

\subsection{Optical microscopy and Scanning electron microscopy}

Optical microscopy in transmitted and reflected light and Scanning Electron Microscopy-Energy Dispersive Spectrometry (SEM-EDS) techniques were used for mineral identification and textural interpretation. SEM-EDS investigation of carbon-coated free surfaces and polished thin sections and blocks was performed using a Jeol JSM-5600 SEM equipped with an Oxford EDS, at the Department of Geology and Geoenvironment, N.K.U.A. The conditions for semi-quantitative analyses were: Accelerating Voltage: $20 \mathrm{kV}$, Beam Current: 0,5 nA, Livetime: $50 \mathrm{sec}$, Beam Diameter: $<2 \mu \mathrm{m}$.

\subsection{Synchrotron micro-X-ray Absorption Near Edge Structurespectroscopy}

The Synchrotron Radiation (SR) study was conducted at the SUL-X beam line of ANKA Synchotron facility, Karlsruhe Institute of Technology (KIT), Germany. In order to determine the chemical and structural character of Sb an X-ray Absorption Near Edge Structure spectroscopic investigation was performed on the ISSC material in microscale at the $\mathrm{Sb} L_{3}$-edge $(4132 \mathrm{eV})$. Micro-XANES spectra were obtained in the polished blocks after logging of micro-areas using a Zeiss Axio Imager.Z1m (with Axiovision 4.7 software) motorized optical microscope in reflected light. . Elemental Sb, stibnite $\left(\mathrm{Sb}^{3+}{ }_{2} \mathrm{O}_{3}\right)$ and tripuhyite $\left(\mathrm{Fe}^{3+} \mathrm{Sb}^{5+} \mathrm{O}_{4}\right)$, were used as reference materials of various Sb species. The spectra were processed using Athena software (Ravel et al., 2005). 


\section{Results}

\subsection{Mineralogy and textures}

Three pyrite (according to SEM-EDS and PXRD; Kilias et al. 2013a) textures representing relevant generations are distinguished which are linked with initial crystallization and following recrystallization (Wohlgemuth-Ueberwasser et al., 2015). Pyrite 1 includes the most immature textures which are distinctly banded and/or concentrically laminated colloform, as well as oncoid-like and microstromatolite-like (Figs. 1A, B, D, E, F, H, I). More compact but fine-grained porous pyrite aggregates (pyrite 2) (Figs. 1D, I) represents an intermediate stage of the modification of primary precipitates (pyrite 1) to fully massive subhedral to euhedral pyrite 3 (Fig. 1C), as porosity is reduced during replacement and recrystallization processes (Wohlgemuth-Ueberwasser et al., 2015).

\subsection{Mineral chemistry and Sb enrichment (SEM-EDS)}

Antimony is selectively partitioned in pyrite 1 or forms autonomous antimoniferous sulphosalt phases and rare stibnite needles (Fig. 1). Concentrically laminated pyrite 1 shows $\mu$ m-scale compositional variations along the laminae, representing growth zones with different $\mathrm{Fe}$ and $\mathrm{S}$, as well as $\mathrm{Sb}$ and $\mathrm{Pb}$ trace element compositions (Fig. 2). The Fe and $\mathrm{S}$ contents vary from 24.26 to $46.36 \mathrm{wt} \%$ and 40.60 to $54.83 \mathrm{wt} \%$, respectively, related to trace metal substitution in pyrite 1(Reich et al., 2013) (Fig. 2; Table 1).

Table 1 - Summary of chemical composition (semi-quantitative EDS data) for pyrite 1, pyrite 2, orpiment-like phases and unidentified $\mathrm{Pb}-\mathrm{Sb}$ sulfosalts.

\begin{tabular}{|c|c|l|l|l|l|r|r|}
\hline Mineral/Analysis No. & $\mathrm{Fe}$ & \multicolumn{1}{|c|}{$\mathrm{S}$} & $\mathrm{As}$ & $\mathrm{Sb}$ & $\mathrm{Pb}$ & \multicolumn{1}{|c|}{ Total } \\
\hline & \multicolumn{5}{|c|}{$\mathrm{wt} /$} & & \\
\hline Pyrite 1/1 & 43.26 & 52.7 & - & 3.79 & - & 99.75 \\
\hline Pyrite 1/2 & 43.81 & 54.83 & - & 1.26 & - & 99.9 \\
\hline Pyrite 1/3 & 43.33 & 53.3 & - & 1.98 & 1.52 & 100.13 \\
\hline Pyrite 1/4 & 34.66 & 46.26 & - & 8.36 & 11.26 & 100.24 \\
\hline Pyrite 1/5 & 34.64 & 44.93 & - & 9.08 & 11.53 & 100.18 \\
\hline Pyrite 1/6 & 44.29 & 53.54 & - & 2.13 & - & 99.96 \\
\hline Pyrite 1/7 & 34.87 & 44.91 & - & 8.47 & 12.30 & 100.55 \\
\hline Pyrite 1/8 & 40.70 & 49.12 & - & 3.76 & 6.44 & 100.02 \\
\hline Pyrite 1/9 & 39.31 & 48.40 & - & 4.39 & 8.29 & 100.39 \\
\hline Pyrite 1/10 & 40.89 & 49.53 & - & 3.58 & 6.31 & 100.31 \\
\hline Pyrite 1/11 & 41.66 & 49.92 & - & 2.76 & 5.65 & 99.99 \\
\hline Pyrite 1/12 & 41.65 & 50.22 & - & 2.58 & 5.80 & 100.26 \\
\hline Pyrite 1/13 & 24.26 & 40.60 & - & 27.21 & 8.22 & 100.29 \\
\hline Pyrite 1/14 & 39.64 & 51.68 & - & 8.95 & - & 100.27 \\
\hline Pyrite 1/15 & 28.37 & 43.40 & - & 22.01 & 6.32 & 100.00 \\
\hline Pyrite 1/16 & 44.36 & 53.20 & - & 2.44 & - & 100.00 \\
\hline Pyrite 1/17 & 40.57 & 54.29 & - & 5.13 & - & 100.00 \\
\hline Pyrite 2/7 & 46.36 & 52.79 & 1.84 & - & - & 100.99 \\
\hline Pyrite 2/8 & 45.35 & 53.28 & 1.2 & - & - & 99.83 \\
\hline Orpiment-like/1 & - & 42.10 & 57.47 & 0.33 & - & 99.9 \\
\hline Orpiment-like/2 & - & 41.11 & 58.74 & 0.25 & - & 100.1 \\
\hline Orpiment-like/3 & - & 36.98 & 46.97 & 16.09 & - & 100.09 \\
\hline Pb-Sb sulfosalt/1 & & 18.83 & & 31.84 & 49.22 & 99.89 \\
\hline Pb-Sb sulfosalt/2 & & 18.14 & & 29.07 & 51.42 & 98.64 \\
\hline Pb-Sb sulfosalt/3 & & 18.81 & & 30.35 & 48.77 & 97.94 \\
\hline Pb-Sb sulfosalt/4 & & 18.37 & & 32.81 & 46.40 & 97.59 \\
\hline
\end{tabular}



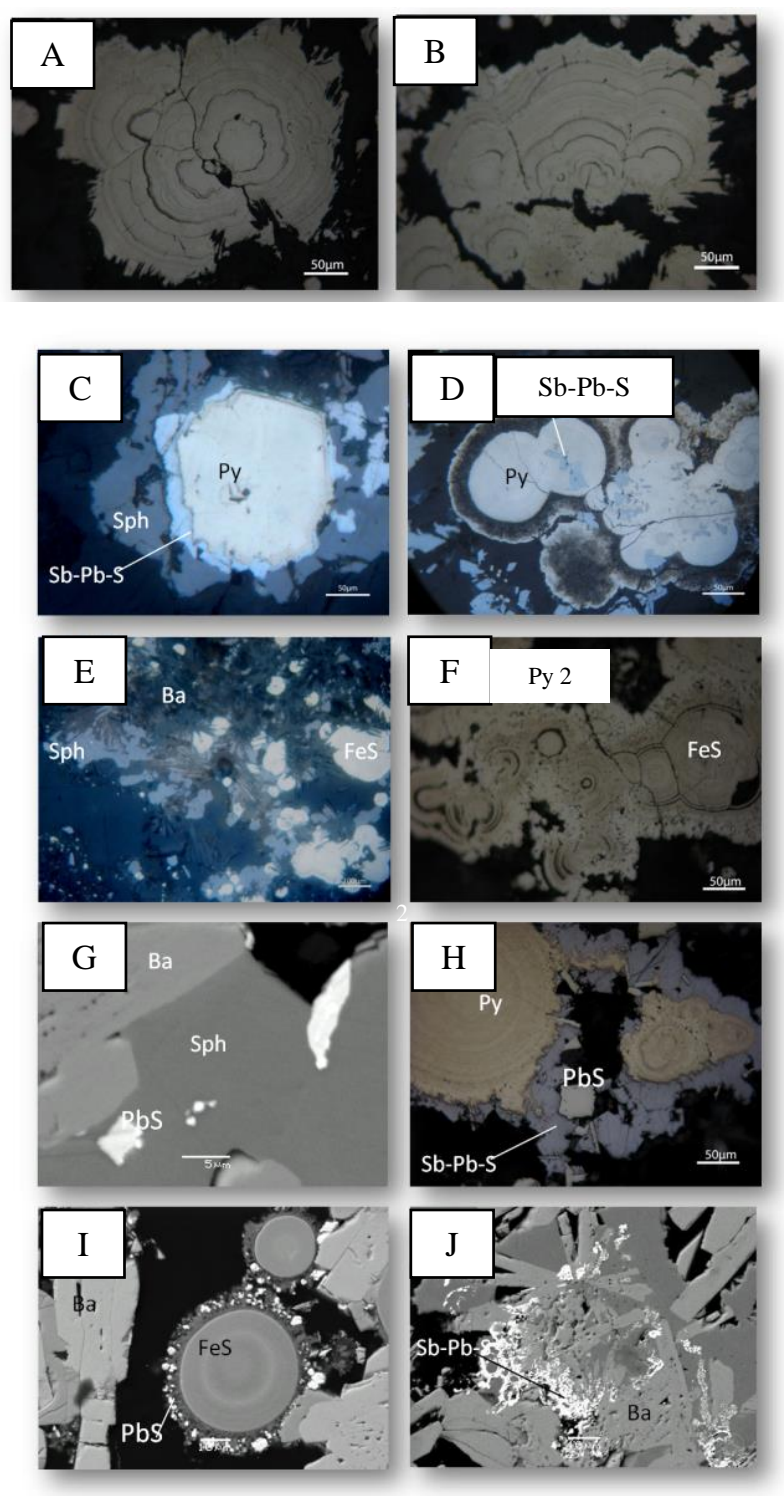

Figure 1 - Photomicrographs in reflected light (RLP) and BSE images of ISSC phases. (A, B) RLP of closely-packed aggregates of bulbous, oncoid-like and microstromatolite-like pyrite 1; (C) RLP of idiomorphic crystal of pyrite 3 (Py) mantled by Sb-Pb-sulfosalts (Sb-Pb-S) and later sphalerite (Sph); (D) RLP of anhedral Sb-Pb-sulfosalt inclusions in concentrically laminated pyrite 1overgrown by thin porous pyrite 2; Sb-Pb-sulfosalts also shown; (E) RLP of clusters of pyrite $1\left(\mathrm{FeS}_{2}\right)$ set in a barite matrix mantled by sphalerite; (F) RLP of zoned colloform pyrite $1\left(\mathrm{FeS}_{2}\right)$ overgrown by a layer of spongy/porous pyrite 2(Py 2); (G) BSE image showing galena $(\mathrm{PbS})$ inclusions in sphalerite $(\mathrm{Sph})$ intergrown with concentrically laminated pyrite 1; (H) concentrically laminated pyrite 1 (Py) mantled by pyrite 2 and anhedral to subhedral intergrowths of $\mathrm{Sb}$-Pb-sulfosalts and galena (PbS); (I) $\mathrm{BSE}$ image of pyrite 1 surrounded by highly porous pyrite 2 with inclusions of galena (PbS); (J) BSE image of dendritic Sb-Pb sulphosalts (Sb-Pb-S, white) mantling pyrite 1, sphalerite (dark grey) and barite laths (light gray). 
Zones "bright" in BSE are enriched in Sb (up to $27.21 \mathrm{wt} \%$ ) and $\mathrm{Pb}$ (up to $12.30 \mathrm{wt} \%$ ) (Table 1), whereas zones "'dark grey" in BSE are trace element-poor (Sb up to $2.13 \mathrm{wt} \%, \mathrm{~Pb}$ was not detected). Porous pyrite 2 overgrowths contains As (up to $1.84 \mathrm{wt} \%$ ), but no detectable $\mathrm{Sb}$ or $\mathrm{Pb}$. Euhedral pyrite 3 is nearly stoichiometric devoid of detectable amounts of Sb and trace metals. Antimony contents up to 16.09 wt \% have been measured along "bright" in BSE growth zones of orpiment $\left(\mathrm{As}_{2} \mathrm{~S}_{3}\right)$-type As-sulphide phases of the OAsL (Table 1); moreover, SEM-EDS spectra collected from amorphous ferrihydrite-type Fe-(hydrated)-oxyhydroxides of the $\mathrm{SFeC}$, and amorphous $\mathrm{Sb}-\mathrm{Zn}$ sulfosalt phases of the IPCN have revealed clear signals for Sb (Gousgouni, 2014). It should be noted that the data presented in Table 1 concern preliminary semi-quantitative analyses whereas accurate EPMA (SEM-WDS) analyses, aiming in the elucidation of the exact chemical formula of the phases, will be a subject of future research.

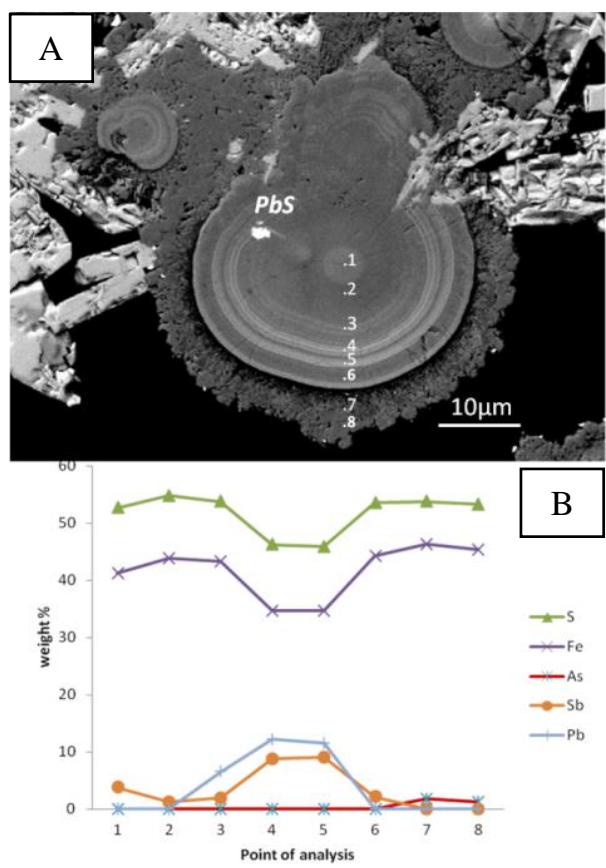

Figure 2 - (A) Backscattered electron (BSE) image, and elemental profiles (EDS semiquantitative analyses) across concentrically laminated pyrite 1 with embedded galena (white), overgrown by thin porous spongy pyrite 2. (B) Element profile across pyrite 1 oncoid, by EDS spot analyses (Numbers on $x$-axis refer to analysis points) (see text for discussion).

\subsection{Speciation of $\mathrm{Sb}$ in pyrite 1 by micro-XANES}

Figure $3 \mathrm{~A}$ shows the normalized $\mathrm{Sb} L_{3}$-edge XANES spectra recorded from pyrite 1 of the ISSC material, and Figure XB shows derivatives of the normalized Sb $L_{3}$ XANES spectra of the sample, compared to selected reference $\mathrm{Sb}$ spectra. Note that $\mathrm{Sb}_{2} \mathrm{O}_{3}$ is not pure and seems to contain some $\mathrm{Sb}^{5+}$ (see the peak in its derivative at about $4143.6 \mathrm{eV}$ ) which may have shifted the position of the $\mathrm{SB}_{2} \mathrm{~S}_{3}$ flank to a higher energy position than for pure $\mathrm{Sb}_{2} \mathrm{~S}_{3}$. The position of the second derivative peak of the sample spectrum plots significantly before the $\mathrm{Sb}^{3+}$ peak.

\section{Discussion}

Four (4) distinct modes of Sb enrichment of various minerals of ore-grade samples $(\leq 2 \mathrm{wt} \% \mathrm{Sb})$ belonging to different mineralogical zones of the Kolumbo chimneys (i.e. ISCC, OAsL, SFeC, 
IPCN): (A) High concentrations (up to $27.2 \mathrm{wt} \% \mathrm{Sb}$ ) occur in $\mu$-scale concentric zones of colloform pyrite 1 (ISSC). Here, micro-XANES spectra at the $\mathrm{Sb} L_{3}$-edge (Fig. 3) confirms the
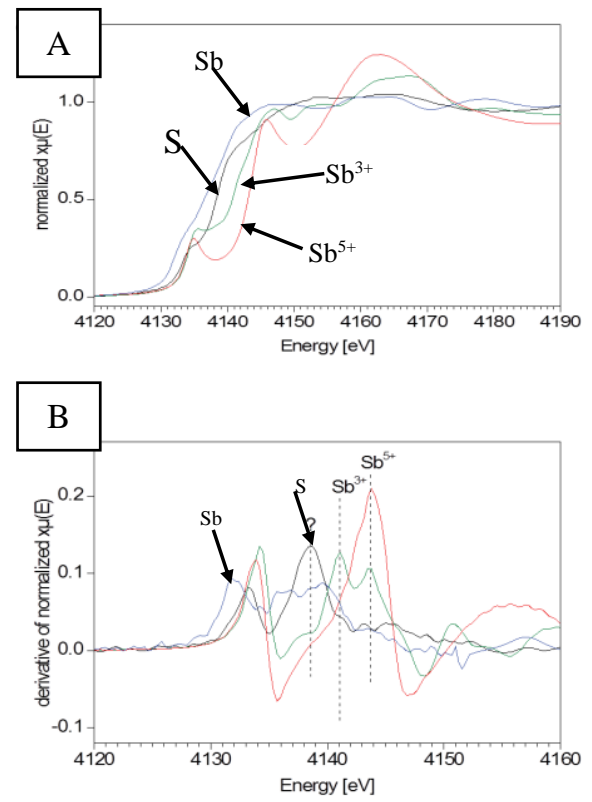

Figure 3 - (A) Normalized (edge jump of 1) Sb $L_{3}$ XANES spectra and derivatives of the normalized $\mathrm{Sb} L_{3}$ XANES spectra(B) of the sample (S) compared to the spectra of elemental $\mathrm{Sb}(\mathrm{Sb}), \mathrm{Sb}^{3+}{ }_{2} \mathrm{O}_{3}\left(\mathrm{Sb}^{3+}\right)$ and Tripuhyite $\left(\mathrm{Fe}^{3+} \mathrm{Sb}^{5+} \mathrm{O}_{4}\right)\left(\mathrm{Sb}^{5+}\right)$ (Kilias et al., 2013b) (see text for discussion).

preferential partitioning of $\mathrm{Sb}$ within pyrite 1, and further reveals the possible dominance of the reduced relatively more toxic trivalent (or lower valence) $\left(\mathrm{Sb}^{3+}\right)$, rather than pentavalent $\left(\mathrm{Sb}^{5+}\right)$ species; this comes in accordance with the high organic carbon content of the ISCC (Corg $\leq 5.3 \%$ TOC) (Kilias et al., 2013a); (B) Unidentified non-stoichimetric Pb_Sb sulphosalt phases; (C) High concentrations of $\mathrm{Sb}$ (up to $16 \mathrm{wt} \%$ ) are also found in growth zones of amorphous colloform banded orpiment $\left(\mathrm{As}_{2} \mathrm{~S}_{3}\right)$-type sulfide phases $(\mathrm{OAsL})$; and, (D) Antimony is hosted by poorly ordered ferrihydrite-type Fe (oxy)hydroxides (SFeC), and amorphous Zn_Sb sulphosalt phases (IPCN).

The systematic $\mathrm{Sb}$ (and $\mathrm{Pb}$ ) variations between different growth zones (Fig. 2) may be explained by variable fluid conditions during pyrite 1 growth or changes in the physicochemical parameters of the discharging parental fluids linked to the episodic nature of the Kolumbo hydrothermal vent system (cf. Maslennikov et al., 2009; Wohlgemuth-Ueberwasser et al., 2015; Keith et al., 2016). Variations in the physicochemical parameters of hydrothermal fluids, namely temperature, $\mathrm{pH}$, redox conditions, salinity and ligand availability, coupled by magmatic volatile contribution, are known to influence trace element composition of pyrite from modern submarine hydrothermal sulfide ores (e.g. Wohlgemuth-Ueberwasser et al., 2015; Keith et al., 2016, and references therein). Alternatively, these variations can evolve from ultra-local fluid composition variations due to shortlived fluid flow events linked to a seismic cycle, or they may suggest different chemical microenvironments within chimneys that may arise from geomicrobiological processes (Kristall et al., 2011).

For seafloor hydrothermal vent precipitates, mineral texture is a measure of the maturity of the precipitates (i.e.variations in the crystallization sequence and texture of pyrite and other sulphides/sulfosalts depicted in Fig.1), which also influences the mobility of trace metals during the course of dissolution-reprecipitation processes within the vent edifices during later stage 
hydrothermal activity, alteration and recrystallization; the latter might liberate trace elements to be incorporated into different phases (Wohlgemuth-Ueberwasser et al. 2015). The most immature textures are those of pyrite 1 (Fig. 1) which may have formed directly from hydrothermal fluids during the early stages of chimney growth (Wohlgemuth-Ueberwasser et al. 2015; Keith et al., 2016). The final stage of recrystallization during the mature stage of chimney growth are represented by samples with well-defined, massive textures consisting of interlocking subhedral to euhedral minerals (i.e. pyrite 3; Pb-Sb sulfosalts; Fig. 1) which formed at different (higher?) temperature (Wohlgemuth-Ueberwasser et al. 2015). Consequently, pyrite 1 may have liberated $\mathrm{Sb}$ and $\mathrm{Pb}$ during hydrothermal recrystallization to form galena, and $\mathrm{Pb}-\mathrm{Sb}$ sulfosalt phases. Because, pyrite 2 and pyrite 3 are devoid of $\mathrm{Pb}$ and $\mathrm{Sb}$ (Gousgouni, 2014), it appears that more compact but porous pyrite 2 represents an intermediate stage of the modification of primary precipitates (pyrite 1) to fully massive texture (pyrite 3), as porosity is reduced during recrystallization processes (WohlgemuthUeberwasser et al. 2015). The tendency for a trace element depletion in late pyrite compares well with that reported for several ancient massive sulfide deposits (e.g. Maslennikov et al., 2009) and the modern seafloor (Keith et al., 2016).

Previous studies suggested different mechanisms for the incorporation of trace elements in pyrite. For $\mathrm{Sb}$ these possible mechanisms include substitution into the pyrite lattice at low temperature, non-stoichiometric substitution, and the possibility that Sb may simply be present as nanoparticles (e.g. Maslennikov et al., 2009; Deditius et al., 2011). Synchrotron radiation $\mu$-XRF elemental distribution maps for $\mathrm{Sb}, \mathrm{Fe}, \mathrm{Zn}$, and As in concentrically laminated pyrite 1 (Kilias et al 2013b) has revealed that $\mathrm{Fe}, \mathrm{Zn}$, As and $\mathrm{Sb}$ show laminae parallel quasi-linear distributions. Zn and Fe partly positively correlate, and $\mathrm{As}$ and $\mathrm{Sb}$ are also positively correlated in a linear manner parallel to the $\mathrm{Fe}$ and $\mathrm{Zn}$ distribution with some spots of elevated concentrations. These correlations in conjunction with the abundances of $\mathrm{Sb}$ and $\mathrm{Pb}$ that vary inversely with $\mathrm{Fe}$ and to $\mathrm{S}$ along geochemical profiles across pyrite 1 globules (Fig. 2), suggest that $\mathrm{Sb}$ and $\mathrm{Pb}$ occur either as homogeneously distributed nano-inclusions and/or lattice bound trace elements (Reich et al., 2013; Keith et al., 2016).

Antimony fixation in solid phases at submarine hydrothermal vents is essential for reducing the high hydrothermal flux of this toxic element to seawater and is an important part of the biogeochemical $\mathrm{Sb}$-cycle. The solid phases that were found to fix $\mathrm{Sb}$ on the Aegean seafloor at Kolumbos are proved crucial for reducing the high hydrothermal flux of this notorious environmental toxin to seawater, near the fishing area of Santorini that is also one of the most popular tourist places in the world. Moreover, the observed enrichment of $\mathrm{Sb}^{3+}$ (toxic trivalent species) emphasize the weight of shallow-submarine geothermal activity as a potential source of toxic metals $\left(\mathrm{Sb}^{3+}\right)$ during seafloor weathering, and/or natural disasters (i.e. explosive volcanic/hydrothermal, and seismic activity).

\section{Acknowledgments}

Support for the operation of the E/V Nautilus was provided by the U.S. National Oceanic and Atmospheric Administration (NA06OAR4600140, NA10OAR4600127), Office of Ocean Exploration (OCE-0452478), and the Ocean Exploration Trust. The officers and the crew of the E/V Nautilus are gratefully acknowledged for their important and effective contribution to the field work and sampling. We acknowledge funding from the Special Account for Research Grants, National and Kapodistrian University of Athens (70/4/11078, 70/3/11401) and the Karlsruhe Institute of Technology-ANKA Synchrotron Radiation Facility (ENV-199).

\section{References}

Amarasiriwardena, D. and Wu, F., 2011. Antimony: Emerging toxic contaminant in the environment, Microchemical Journal, 97, 1-3.

Cantner, K., Carey, S. and Nomikou, P., 2014. Integrated volcanologic and petrologic analysis of the 1650AD eruption of Kolumbo submarine volcano, Greece, Journal of Volcanology and Geothermal Research, 269, 28-43. 
Carey, S., Nomikou, P., Croff-Bell, K., Lilley, M., Lupton, J., Roman, C., Stathopoulou,E., Bejelou, K. and Ballard, R., 2013. CO2 degassing from hydrothermal vents at Kolumbo submarine volcano, Greece and the accumulation of acidic crater water, Journal of Geochemical Exploration, 20, 223-302.

Deditius, A., Utsunomiya, S., Reich, M., Kesler, S.E., Ewing, R.C., Hough, R. and Walshe, J., 2011. Trace metal nanoparticles in pyrite, Ore Geol. Rev., 42, 32-46.

EU Commission, 2014. Report on critical raw materials for the EU. Available online at: http://mima.geus.dk/report-on-critical-raw-materials_en.pdf.

Filella, M., Belzile, N. and Chen Yu-Wei., 2002a. Antimony in the environment: a review focused on natural waters, I Occurrence, Earth-Science Reviews, 57, 125-176.

Filella, M., Belzile, N., and Chen, Yu-Wei., 2002b. Antimony in the environment: a review focused on natural waters, II Relevant solution chemistry, Earth-Science Reviews, 59, 265-285.

Filella, M., Williams, P.A. and Belzile, N., 2009. Antimony in the environment: Knows and unknowns, Environ, Chem., 6, 95-105.

Fouquet, Y., Cambon, P., Etoubleau, J., Charlou, J.L., Ondréas, H., Barriga, F.J.A.S., Cherkashov, G., Semkova, T., Poroshina, I., Bohn, M., Donval, J.P., Henry, K., Murphy, P. and Rouxel, O., 2010. Geodiversity of hydrothermal processes along the Mid-Atlantic Ridge and ultramafic-hosted mineralization: a new type of oceanic $\mathrm{Cu}-\mathrm{Zn}-\mathrm{Co}-\mathrm{Au}$ volcanogenic massive sulfide deposit. In: Rona, P.A., Devey, C.W., Dyment, J. and Murton, B.J., eds., Diversity of Hydrothermal Systems on Slow Spreading Ocean Ridges, Geophysical Monograph, 188, 321-367.

Gousgouni, M., 2014. Antimony fixation in solid phases at the hydrothermal field of the Kolumbo submarine arc-volcano (Santorini): Deposit model and environmental implications, Unbubl. M.Sc. thesis, National and Kapodistrian University of Athens, 167 pp.

Hübscher, C., Ruhnau, M. and Nomikou, P., 2015. Volcano-tectonic evolution of the polygenetic Kolumbo submarine volcano/Santorini (Aegean Sea), Journal of Volcanology and Geothermal Research, 291, 101-111.

Keith, M, Häckel F., Haase, K.M., Schwarz-Schampera, U. and Klemd, R., 2016. Race element systematics of pyrite from submarine hydrothermal vents, Ore Geology Reviews, 72(1), 728745, doi:10.1016/j.oregeorev.2015.07.012.

Kilias, S.P., Godelitsas, A., Gamaletsos, P., Mertzimekis, T.J, Nomikou, P., Goettlicher, J., Steininger, R., Argyraki, A., Gousgouni, M. and Papanikolaou, D., 2013b. Antimony in hydrothermal chimneys of Kolumbo shallow-submarine vent field (Santorini, Greece) Goldschmidt 2013 Conference Abstracts, Goldschmidt 2013 Conference Abstracts, www.minersoc.org, doi:10.1180/minmag.2013.077.5.11.

Kilias, S.P., Nomikou, P., Papanikolaou, D., Polymenakou,P.N., Godelitsas, A., Argyraki, A., Carey, S., Gamaletsos, P., Mertzimekis, T.J, Stathopoulou E., Goettlicher, J., Steininger, R., Betzelou, K., Livanos, I., Christakis, C., Bell, K.C. and Scoullos, M., 2013a. New insights into hydrothermal vent processes in the unique shallow-submarine arc-volcano, Kolumbo (Santorini), Greece. Sci. Rep., 3, 2421, doi: 10.1038/srep02421.

Kristall, B., Nielsen, D., Hannington, M.D., Kelley, D.S. and Delaney, J.R., 2011. Chemical microenvironments within sulfide structures from the Mothra hydrothermal field: Evidence from high resolution zoning of trace elements, Chemical Geology, 290, 12-30.

Majzlan, J. and Fillela, M., 2012, Editorial, In: Antimony, Majzlan, J. and Filella, M., eds., Chemie der Erde - Geochemistry, 72(4), 1-66, doi: 10.1016/j.chemer.2012.04.002.

Maslennikov, V.V., Maslennikova, S.P., Large, R.R. and Danyushevsky, L.V., 2009. Study of trace element zonation in vent chimneys from the Silurian Yaman-Kasy volcanic hosted massive sulfide deposit (Southern Urals, Russia) using laser ablation-inductively coupled plasma mass spectrometry (LA-ICPMS), Econ. Geol., 104, 1111-1141.

Melekestseva, I.Y., Tret'yakov, G.A., Nimis, P., Yuminov, A.M., Maslennikov, V.V., Maslennikova, S.P., Kotlyarov, V.A., Beltenev, V.E., Danyushevsky, L.V. and Large, R., 2014. Barite-rich massive sulfides from the Semenov-1 hydrothermal field (Mid-Atlantic 
Ridge, $\left.13^{\circ} 30.87^{\prime} \mathrm{N}\right)$ : Evidence for phase separation and magmatic input, Marine Geology, 349, 37-54.

Nomikou, P., Papanikolaou, D., Alexandri,M., Sakellariou, D. and Rousakis, G., 2013. Submarine volcanoes along the Aegean Volcanic Arc, Tectonophysics, 507-508, 123-146.

Ravel, B. and Newville, M., 2005. ATHENA, ARTEMIS, HEPHAESTUS: data analysis for X-ray absorption spectroscopy using IFEFFIT, J. Synchrotron Radiat., 12, 537-541.

Reich, M., Deditius, A., Chryssoulis, S., Li, J.-W., Ma, C.-Q., Parada, A.P., Barra, F. and Mittermayr, F., 2013. Pyrite as a record of hydrothermal fluid evolution in a porphyry copper system: a SIMS/EPMA trace element study, Geochim. Cosmochim. Acta, 102, 42-62.

Sigurdsson, H., Carey, S., Alexandri, M., Vougioukalakis, Croff, K., Roman, C., Sakellariou, D., Anagnostou, C., Rousakis, G., Ioakim, C., Gogou, A., Ballas, D., Misaridis, T. and Nomikou, P., 2006. Marine Investigations of Greece's Santorini Volcanic Field, EOS 87, 337-339.

Wohlgemuth-Ueberwasser, C.C., Viljoen, F., Petersen, S. and Vorster, C., 2015. Distribution and solubility limits of trace elements in hydrothermal black smoker sulfides: An in-situ LA-ICPMS study, Geochimica et Cosmochimica Acta, 159, 16-41. 